\title{
PENGARUH METODE RANGKAIAN BERMAIN DAN RANGKAIAN LATIHAN TERHADAP KETERAMPILAN BERMAIN SEPAKBOLA
} (Kuasi Eksperimen Pemain Sepakbola SSB Putra Ranah Minang Kota Padang)

\author{
Drs. Yulifri, M.Pd ${ }^{1}$, Drs. Ali Asmi,M.Pd² \\ ${ }^{1}$ Universitas Negeri Padang, Pendidikan Jasmani, Padang, Indonesia \\ ${ }^{2}$ Universitas Negeri Padang, Pendidikan Jasmani, Padang, Indonesia \\ Email: yulifri.yulifri@gmail.com
}

\begin{abstract}
Based on a preliminary observation, it could be seen that the football players of SSB Putra Ranah Minang Padang City possessed poor quality of basic football techniques. Besides, it also revealed the fact that training programs were not structured well and players were not serious while training programs occured. This was a quasi-experiment design. The instrument used in this study was a test of football playing skills. Data were analyzed using t-test analysis. The results of data analysis showed that: (1) there were differences of skills between the group of playing method and the group of training method.
\end{abstract}

Key words : Playing Method, Training Method, Football Skills

\begin{abstract}
Abstrak
Berdasarkan pengamatan peneliti di lapangan terlihat bahwa pemain SSB Putra Ranah Minang Kota Padang keterampilan bermain sepakbolanya masih rendah, dan masih banyak pemain yang belum menguasai teknik dasar sepakbola, selain itu program latihan yang belum terstruktur dan pemain yang masih asal-asalan dalam mengikuti latihan. Jenis penelitian ini adalah eksperimen semu (quasy experiment), Instrument yang digunakan dalam penelitian ini adalah tes keterampilan bermain sepakbola. Data dianalisis dengan menggunakan analisis Uji t-Tes.Hasil analisis data menunjukkan bahwa: (1) terdapat perbedaan keterampilan bermain sepakbola antara kelompok metode rangkaian bermain dengan kelompok metode rangkaian latihan.
\end{abstract}

Kata Kunci: Metode Rangkaian Bermain, Metode Rangkaian Latihan, Keterampilan Bermain Sepakbola

\section{PENDAHULUAN}

Dalam meningkatkan keterampilan bermain sepakbola diperlukan latihan yang efektif dan efisien. Metode latihan merupakan suatu alat/cara pembelajaran yang dilakukan untuk belajar bermain sepakbola. Sesuai dengan persyaratan kondisi dalam mendukung prestasi cabang olahraga, maka kemampuan gerak dan teknik yang sesuai akan dikembangkan melalui berbagai metode latihan 
yang tepat. Melalui metode latihan dapat di susun beberapa bentuk latihan untuk meningkatkan keterampilan bermain sepakbola, diantaranya adalah metode bentuk bermain, metode rangkaian bermain, metode bentuk latihan, metode rangkaian latihan, metode elementer, metode global, dan lain sebagainya.

Rangkaian bermain merupakan metode latihan yang digunakan melalui kegiatan-kegiatan yang kompleks yang dapat mencerminkan terjadinya suatu permainan atau pertarungan di antara dua regu dimana ada yang menang dan kalah. Sedangkan rangkaian latihan dilakukan terhadap elemen-elemen dari bermain untuk latihan teknik baik secara terpisah maupun kombinasi, dimana dalam rangkaian latihan tidak ada lawan. Pelaksanaan metode latihan ini didasarkan pada sasaran yang diinginkan.

Untuk mendapatkan hasil latihan yang baik, tentu dengan metode yang benar, maka kemampuan pelatih menjadi hal yang sangat penting. Pengetahuan dan keterampilan harus dimiliki, sampai kepada hal-hal terperinci tentang cabang olahraga yang dilatihnya, pengetahuan tersebut termasuk teknik, taktik, peraturan pertandingan, sistem latihan, strategi latihan, psikologi dan hal lainnya tentang cabang olahraga yang ia latih.

Metode yang sering digunakan selama ini adalah metode latihan bentuk bermain, bentuk latihan, rangkaian bermain, rangkaian latihan, global, dan elementer. Akan tetapi, kadangkala kalau metode itu saja bisa jadi membosankan, maka dari itu dicarikan alternatif lain.

Didalam Artikel http://de.wikipedia.org/wiki/Methodische_Spielreihe metode rangkaian permainan dalam olahraga mengajarkan urutan rangkaian beberapa permainan, untuk mengurangi kerumitan dalam permainan. Parameter yang mungkin bisa digunakan adalah jumlah pemain, ukuran lapangan, serta materi. keuntungan dari latihan ini pemain tidak akan mengalami kesulitan dari awal permainan, karena kesulitan yang dihadapi dapat disesuaikan dengan kemampuan yang mereka miliki, sehingga motivasi dapat ditingkatkan.

Berdasarkan pendapat tersebut, dengan pemain memiliki motivasi yang tinggi maka secara langsung akan merangsang pemain untuk meningkatkan Agresifitas instrumental yang ada pada dirinya, karena pemain akan merasa percaya diri, mempunyai semangat juang yang tinggi, tidak merasa bosan untuk berlatih dengan metode rangkaian bermain. sehingga dengan begitu pemain akan merasa seperti bertanding dengan sesungguhnya. 
Metode latihan akan sesuai dengan tujuan awal bila di buat sesuai dengan prinsip-prinsip latihan. Berdasarkan penjelasan mengenai prinsip latihan dapat dikemukakan bahwa latihan sangat penting untuk meningkatkan kemampuan dan keterampilan individual dalam prestasi. Menurut Röthig dalam Syafruddin (2004:24) "memilih rangkaian-rangkaian latihan merupakan hal yang penting dalam usaha peningkatan prestasi pemain pada setiap cabang olahraga."

Rangkaian latihan menurut Darwis (1999:43) "rangkaian latihan yang dilakukan terhadap elemen-elemen dari bermain, seperti untuk latihan teknik baik secara terpisah maupun di kombinasi". Dengan rangkaian latihan, pemain memperoleh pengalaman dalam melaksanakan beberapa elemen teknik yang berhubungan satu sama lain.

Disamping itu, Tim Mata Kuliah Sepakbola Fakultas Ilmu Keolahragaan Universitas Negeri Padang (2010) mengemukakan "metode rangkaian latihan digunakan dalam mencapai tujuan terhadap peningkatan kemampuan dari elemen-elemen teknik baik dilakukan secara terpisah maupun secara kombinasi diantara elemen teknik yang saling berhubungan antara satu sama lain".

Dari beberapa pendapat ahli tersebut, dapat dikemukakan bahwa Rangkaian latihan dalam sepakbola merupakan suatu rangkaian latihan melalui langkahlangkah pelaksanaan yang diarahkan pada elemen-elemen teknik, baik secara terpisah-pisah maupun secara kombinasi dari elemen tersebut. Dalam rangkaian latihan adanya pengalaman yang diberikan dari rangkaian latihan akan membiasakan pemain dalam menghadapi situasi dalam suatu permaianan sesungguhnya.

\section{METODE PENELITIAN}

Jenis penelitian ini adalah penelitian quasi experiment, menurut Winarno (2011:61) "penggunaan rancangan penelitian ini dimaksudkan untuk mengungkapkan hubungan sebab akibat dengan cara melibatkan kelompok kontrol di samping kelompok eksperimental". Tujuan penelitian ini untuk melihat pengaruh metode latihan terhadap Keterampilan bermain sepakbola. Populasi penelitian ini adalah pemain yang masuk ke dalam kelompok umur 10-12 tahun berjumlah 83 orang. Teknik pengambilan sampel dalam penelitian ini digunakan teknik purposive sampling. Menurut Winarno (2011:87), teknik purposive sampling digunakan karena alasan dan pertimbangan-pertimbangan tertentu. 


\section{HASIL DAN PEMBAHASAN}

Dari hasil pengukuran sampel dalam kelompok ini yang terdiri dari 2 sampel ( $n=22$ ) skor tertinggi 49,05, skor terendah 32,37, dan jarak pengukuran (range) 19,14, rerata skor 40,81 dan simpangan baku 4.38. distribusi kelompok ini dapat digambarkan dalam tabel 12 distribusi frekuensi:

Tabel 1. Distribusi Frekuensi Data Hasil Tes Keterampilan Bermain Sepakbola Kelompok Metode Rangkaian Bermain (A)

\begin{tabular}{|c|c|c|c|}
\hline \multirow{2}{*}{ No } & \multirow{2}{*}{ Kelas Interval } & \multicolumn{2}{|c|}{ Frekuensi } \\
\cline { 3 - 4 } & & Absolut & Relatif \\
\hline 1 & $32,37-35,71$ & 4 & $18,18 \%$ \\
\hline 2 & $35,72-39,05$ & 3 & $13,64 \%$ \\
\hline 3 & $39,06-42,40$ & 8 & $36,36 \%$ \\
\hline 4 & $42,41-45,74$ & 4 & $18,18 \%$ \\
\hline 5 & $45,75-49,09$ & 3 & $13,64 \%$ \\
\hline \multicolumn{2}{|c|}{ Jumlah } & 22 & $100,00 \%$ \\
\hline
\end{tabular}

Tabel 1. menunjukan bahwa terdapat sebanyak 4 orang $(18,18 \%)$ berada pada kelompok 32,37-35,71, 3 orang (13,64\%) berada pada kelompok 35,7239,05 , 8 orang $(36,36 \%)$ berada pada kelompok $39,06-42,40$, 4 orang $(18,18 \%)$ berada pada kelompok 42,41-45,74, dan 3 orang (13,64\%) berada pada kelompok 45,75-49,09. untuk lebih jelasnya, penjabaran distribusi frekuensi metode latihan di atas dapat dilihat pada histogram berikut:

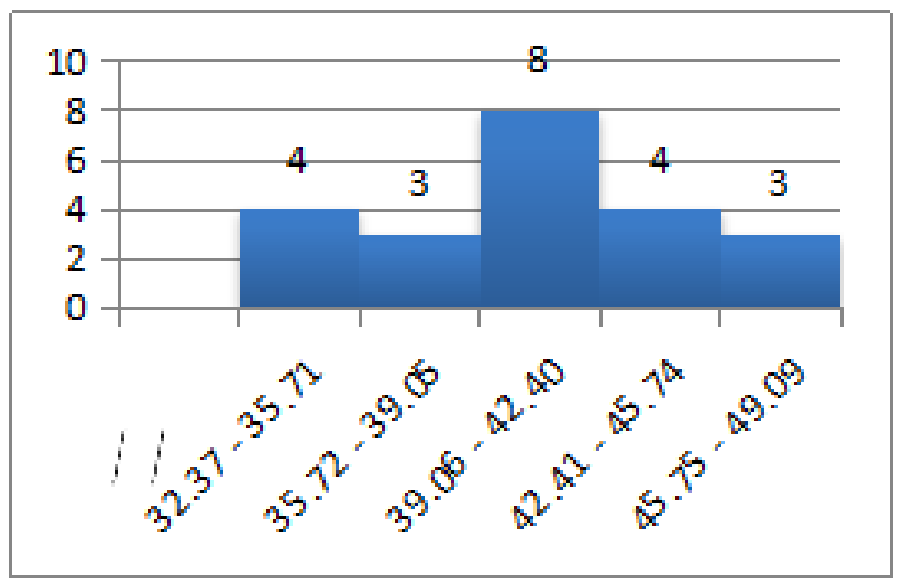

Gambar 1.Histogram Data Hasil Tes Keterampilan Bermain Sepakbola Kelompok Metode Rangkaian Bermain 
E-ISSN 2579-5910

Dari hasil pengukuran sampel dalam kelompok ini yang terdiri dari 2 sampel ( $n=22$ ) skor tertinggi 43,04, skor terendah 34,26, dan jarak pengukuran (range) 5,44 , rerata skor 39,22 dan simpangan baku 2,33. distribusi kelompok ini dapat digambarkan dalam tabel 13 distribusi frekuensi:

Tabel 2. Distribusi Frekuensi Data Hasil Tes Keterampilan Bermain Sepakbola

Kelompok Metode Rangkaian Latihan $\left(\mathrm{A}_{2}\right)$

\begin{tabular}{|c|c|c|c|}
\hline \multirow{2}{*}{ No } & \multirow{2}{*}{ Kelas Interval } & \multicolumn{2}{|c|}{ Frekuensi } \\
\cline { 3 - 4 } & & Absolut & Relatif \\
\hline 1 & $34,26-36,02$ & 1 & $4,55 \%$ \\
\hline 2 & $36,03-37,78$ & 6 & $27,27 \%$ \\
\hline 3 & $37,79-39,55$ & 5 & $22,73 \%$ \\
\hline 4 & $39,56-41,32$ & 5 & $22,73 \%$ \\
\hline 5 & $41,33-43,08$ & 5 & $22,73 \%$ \\
\hline & Jumlah & 22 & $100,00 \%$ \\
\hline
\end{tabular}

Tabel 2. menunjukkan bahwa terdapat sebanyak 1 orang $(4,55 \%)$ berada pada kelompok 34,26-36,02, 6 orang $(27,27 \%)$ berada pada kelompok 36,03-37,78, 5 orang $(22,73 \%)$ berada pada kelompok $37,79-39,55,5$ orang $(22,73 \%)$ berada pada kelompok 39,56-41,32, dan 5 orang (22,73\%) berada pada kelompok 41,33-43,08. untuk lebih jelasnya, penjabaran distribusi frekuensi metode rangkaian latihan di atas dapat dilihat pada histogram berikut:

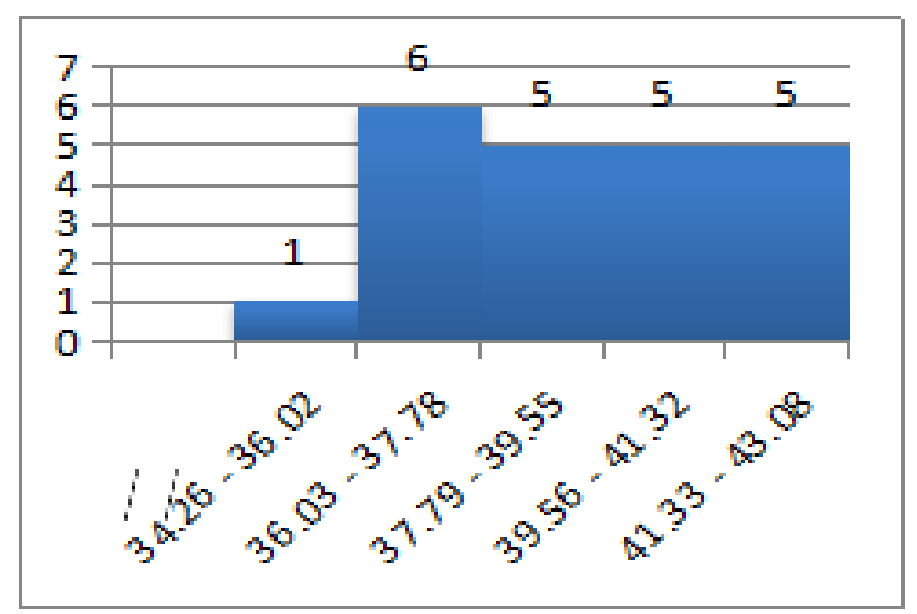

Gambar 2. Histogram Data Hasil Tes Keterampilan Bermain Sepakbola Kelompok Metode Rangkaian Latihan. 
JURNAL SPORTA SAINTIKA

P-ISSN 2502-5651

E-ISSN 2579-5910

\section{KESIMPULAN}

Berdasarkan temuan penelitian maka dapat disimpulkan sebagai berikut: Metode rangkaian bermain lebih efektif digunakan untuk meningkatkan keterampilan bermain sepakbola daripada metode rangkaian latihan.

\section{SARAN}

Saran pemanfaatan penelitian merupakan usulan yang dapat dipertimbangkan saat pemakaian produk. Berikut beberapa usulan pemanfaatan penelitian:

1. Penelitian ini disarankan dipergunakan untuk melakukan evaluasi terhadap Keterampilan bermain sepakbola.

2. Penelitian ini diharapkan dapat menjadi pedoman dan acuan dalam melatih kemampuan keterampilan bermain sepakbola.

\section{DAFTAR PUSTAKA}

Arikunto, Suharsimi. (1995). Manajemen Penelitian. Jakarta: PT. Rineka Cipta.

Bompa, Tudor O. and G.Gregory Haff. (2000). Periodezation, Theory and Methodology of Training. Fifth Edition. Terjemahan Rahantoknam, BE. USA: Human Kinetics.

Darwis, Ratinus. (1999). SepakBola. Padang: FIK UNP.

Fleck, Tom dan Ron Quinn. (2002). Panduan Latihan Sepakbola Andal. USA: Ragged Mountain Press.

Gifford, Clive. (2007). Keterampilan sepakbola. Di terjemahkan oleh Andri Setyawan. Yogyakarta: PT Intan Sejati.

Koger, Robert. (2005). Latihan Dasar Andal Sepakbola Remaja. USA: The United States copyright.

Lutan, Rusli. (1988). Belajar Keterampilan Motorik, Pengantar Teori dan Metode. Jakarta: Depdikbud, Dirjen DIKTI.

Luxbacher, Joseph. (2001). Sepakbola. Jakarta: PT. Raja Grafindo Persada.

Mielke, Danny. (2003). Seri Dasar-dasar Olahraga, Dasar-dasar Sepakbola. Jakarta: Pakar Raya.

Roethig, Peter \& Stefan Groessing. (2004). Pengetahuan Training Olahraga. Terjemahan Syafruddin. Padang: UNP.

Sarwono, W, Sarlito. (2009). Psikologi Sosial. Jakarta: Salemba Humanika.

Sobur, Alex. (2003). Psikologi Umum. Bandung: CV Pustaka Setia.

Sugiyono. (2010). Metode Penelitian Kuantitatif Kualitatif dan R\&D. Bandung: Alfabeta.

Syafruddin. (2011). Ilmu Kepelatihan Olahraga. Padang. UNP Press.

Tim Mata Kuliah Sepakbola FIK UNP. (2010). Buku Ajar Sepakbola. Sukabina. Padang.

Winarno. (2011). Metodologi Penelitian Dalam Pendidikan Jasmani. Media Cakrawala Utama Press. Malang: Universitas Negeri Malang.

Loog Book Dispora Siak. (2007). Kursus Pelatih Sepakbola Lisensi D. Kab Siak.

Loog Book PSSI. (2011). Kursus Pelatih Sepakbola Lisensi D Nasional. Padang.

Pusat Pengembangan Kualitas Jasmani. (2009). Tes Keterampilan Sepakbola Usia 10-12 Tahun: Jakarta.

PSSI. (2012). Kurikulum \& Pedoman Dasar Sepak Bola Indonesia, Untuk Usia Dini (U 5-U 12), Usia Muda (U 13-U 20) \& Senior. Jakarta.

PSSI. (2009) . Peraturan Permainan Sepak Bola. Jakarta. 